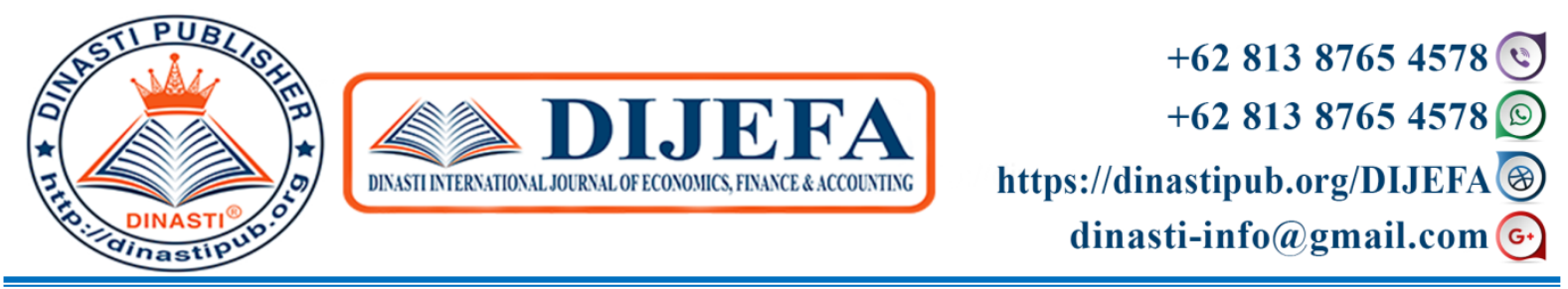

\title{
MULTIPLE REGRESSION : DETEMINANT ON PROFITABILITY AT ISLAMIC COMMERCIAL BANKS IN INDONESIA
}

\author{
Dodi Tisna Amijaya ${ }^{1}$, Siti Komariah ${ }^{2}$, Kartika Pratiwi Putri ${ }^{3}$, Meita Chandra Devi ${ }^{4}$ \\ 1) Fakultas Ekonomi \& Bisnis Universitas Winaya Mukti, Bandung, Indonesia \\ ${ }^{2)}$ Fakultas Bisnis dan Manajemen Universitas Widyatama, Bandung, Indonesia \\ 3) Fakultas Ekonomi \& Bisnis Universitas Winaya Mukti, Bandung, Indonesia \\ 4) Fakultas Ekonomi \& Bisnis Universitas Winaya Mukti, Bandung, Indonesia
}

\begin{tabular}{|l|l|}
\hline $\begin{array}{c}\text { ARTICLE INFORMATION } \\
\text { Received: 16 March 2020 } \\
\text { Revised: 20 March 2020 } \\
\text { Issued: 22 March 2020 }\end{array}$ & $\begin{array}{l}\text { Abstract: The Islamic financial system is potential to } \\
\text { be a locomotive of the national economy and be able to } \\
\text { overcome gaps. One of them is Islamic banking which } \\
\text { is increasingly developing in Indonesia. The } \\
\text { development of Islamic banking is expected to increase } \\
\text { economic growth. For this reason, Islamic banking is } \\
\text { needed which has a healthy financial performance. } \\
\text { This study aims to analyze the effect of NPF, CAR, } \\
\text { and FDR on Profitability at Islamic Commercial } \\
\text { Banks. The data used in this study were obtained from } \\
\text { E-mail: } \\
\text { amijaya07@gmail.com }\end{array}$ \\
$\begin{array}{l}\text { Islamic commercial bank financial statements which } \\
\text { are recorded in the OJK for 2015-2018. The population } \\
\text { in this study is 14 Sharia Commercial Banks in } \\
\text { Indonesia, and using the purposive sampling method, } \\
\text { there are 12 bank samples which will be examined. } \\
\text { The analysis technique used in this study is multiple } \\
\text { linear regression models. The results showed that NPF, } \\
\text { CAR and FDR had a significant effect on profitability. }\end{array}$ \\
Keywords : NPF, CAR, FDR, Profitability.
\end{tabular}

\section{INTRODUCTION}

The development of Islamic financial markets in Indonesia over the past few years is quite rapid, although the Islamic financial market is a new element in Indonesia (Alamsyah, 2010). This development is marked by the increasing number of Islamic financial institutions in Indonesia, such as Islamic banking, Islamic insurance, Islamic mutual funds, and other Islamic financial institutions. Islamic banking is one of the Islamic financial institutions that is currently developing in Indonesia. This can be seen in Figure 1.1 where Islamic banking has the second largest asset after state sukuk. 


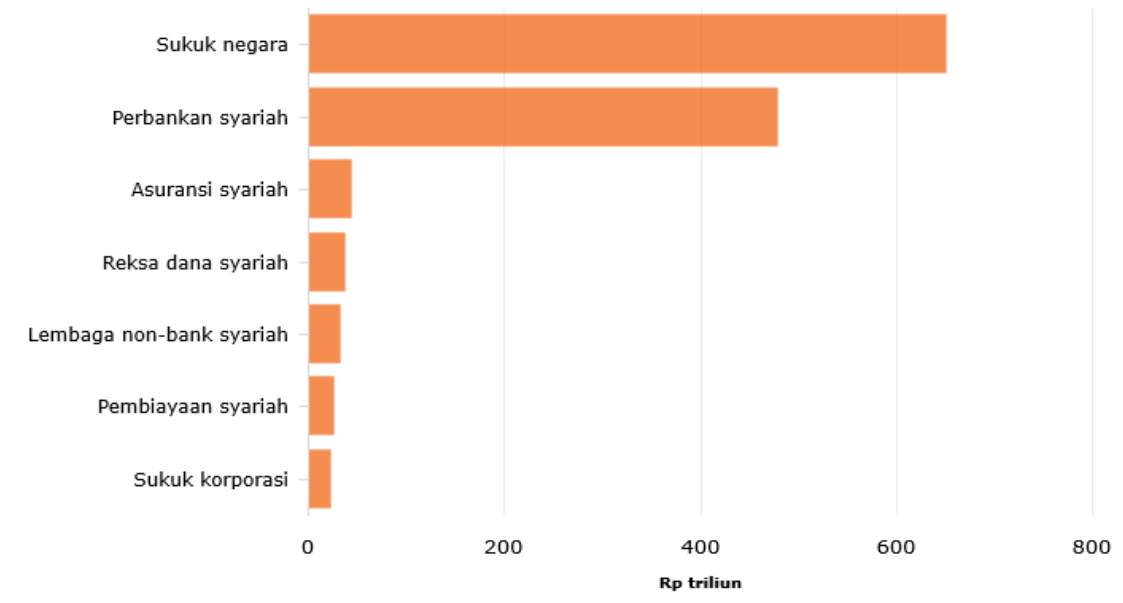

Source : Financial Services Authority (OJK)

Figure 1.1. Asset of Islamic Financial Industry in 2019

The Islamic banking industry has shown positive developments from year to year. During the 2014-2018 period, Islamic banking was able to record a Compounded Annual Growth Rate (CAGR) of $15 \%$, higher than the national banking industry which recorded a CAGR of $10 \%$ (www.cnbcindonesia.com/2019). But there are still many challenges that must be resolved by Islamic banking, namely improving the quality of financing, capital and improving IT to strengthen transactional banking and digital banking. In addition, the performance of Islamic banking is currently slow, especially the problem of strengthening capital, liquidity and efficiency. The retardation in the Islamic banking industry was also followed by a retardation in the national Islamic financial industry. The growth of the national Islamic financial industry until May 2019 was $11.25 \%$, slowing down from the end of 2018 at $13.98 \%$ (www.ojk.co.id/2019).

Business activities in the banking sector, including Islamic banking, use the principle of trust in its activities, therefore the performance of banks must always fulfill the wishes of the public so that banks get the trust of the public as their market share. Thus, Islamic banking must increase its credibility so that more people use the banking sector as a facilitator for their economic activities. One way to increase credibility is to increase profitability. Because the level of Islamic profit is not enough to affect the results given to the public as its customers, it is important for Islamic banking to continue to increase its profitability.

Profitability is one of the right indicators to measure the performance of a company, which is to show how much the company's ability to generate profits is a benchmark for the company's performance. High profitability shows the better performance of the company. Theoretically there are several indicators to measure bank profitability, such as: Return On Assets (ROA), Return On equity (ROE) and Net Interest Margin (NIM). This study using ROA because this ratio describes bank profits in general. Return on Assets (ROA) is a leading indicator of bank profitability (Siraj and Pillai, 2012). The higher ROA, the higher the profit to be achieved and the better position in using its assets. This shows how banks can turn their assets into net income (Samad and Hassan, 2010). These are the average banking industry ROA developments: 


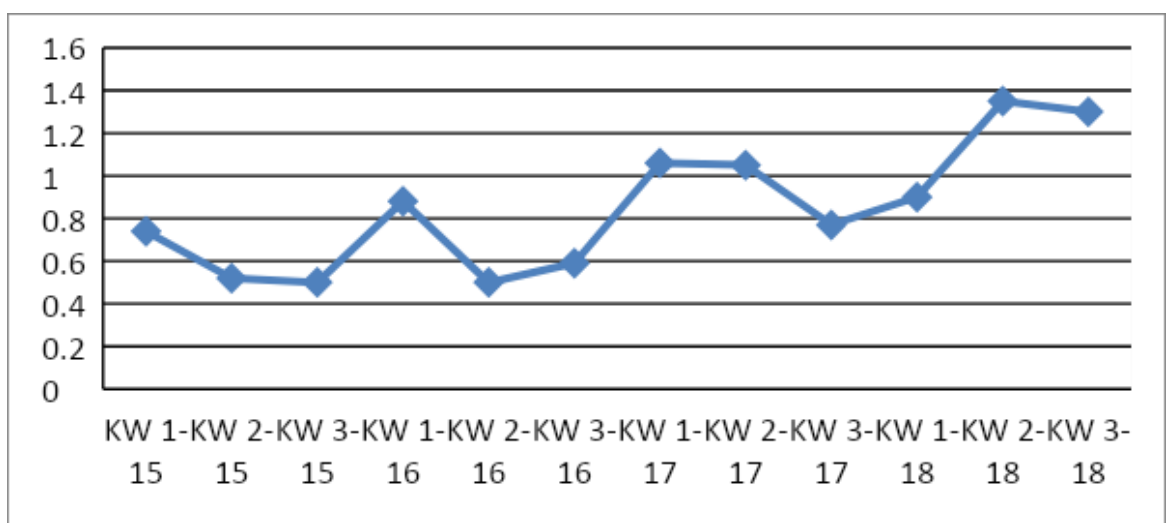

Source: Financial Services Authority (OJK)

Figure 1.2: The Development of Return On Assets Banking Industry in 2014-2018

If you see the ROA ratio with developments per month in Islamic banks has a fluctuating trend but tends to be sharper decline, it can be seen from the graph of 2015 - 2018 which experienced ups and downs in profitability performance is not good for the Islamic banking industry to show its credibility. In the period 2015 - 2018, Islamic banking has an average ROA value of $0.85 \%$. ROA has criteria that indicate health conditions in a company or industry. With a value of $0.85 \%$, it shows that the Islamic banking industry in the 2015 2018 period was in a reasonably healthy condition. Of course it is still very far in a very healthy condition considering that Indonesia is a huge opportunity to turn the Islamic banking industry into a large and credible industry because Indonesia is predominantly Muslim.

Therefore we need to know the factors that influence the profitability of the Islamic banking industry. In this study using three financial ratios namely Non Performing Financing (NPF), Capital Adequacy Ratio (CAR), and Financing to Deposit Ratio (FDR). Even though Islamic finance is developing, empirical research in this industry is still limited, and several studies that have been conducted have experienced difficulties in data limitations. Several studies that have examined the factors that influence the profitability of the Islamic banking industry are Ben Khediri et al. (2010), Smaoui and Salah (2011), Masood and Rachdi (2014), Paulin and Wiryono (2015), Erlangga (2016), Simatupang and Smarzlay (2016)

\section{LITERATURE REVIEW}

Islamic banks are financial institutions that operate like conventional banks but adhere to Sharia principles. Therefore, these banks are not involved in usury in any financial transactions that are contrary to Sharia principles (Alharbi, 2017). The characteristics of the Islamic banking system which operate on the principle of profit sharing provide an alternative banking system that is mutually beneficial to the public and banks, and the high aspects of fairness in trade, ethical investment, promoting the values of togetherness and brotherhood in production, and avoiding speculative activity in financial transactions (Subaweh, et al, 2012). There are many factors that affect the performance and health of Islamic banking. Islamic banking health assessment in this study refers to the RGEC method (Risk Profile, Good Corporate Governance, Earning, and Capital). This assessment uses the RGEC method in which the component will be assessed based on a comprehensive and structured analysis of the rankings with due to the materiality and significance of each factor determined to be a 
composite rating. Composite Rating is a rating obtained from the results of calculations in assessing the soundness of a bank. This Composite Rating will reflect the category of soundness of the bank. The implementation of this method is contained in SE BI number 13/24 / DPNP on 25 October 2011 concerning Rating of Soundness of Commercial Banks. This study uses Non Performing Financing (NPF) as a measurement of risk profile, Capital Adequacy Ratio (CAR), and Financing to Deposit Ratio (FDR) as a measurement of capital and we see the effect on Return On Assets as a measurement of Earning.

\section{Non Performing Financing (NPF)}

In Islamic banking, there is no loan in the distribution of funds, but the activity of channeling funds carried out by Islamic banks is more directed towards financing. Non Performing Financing shows the ability of bank management to manage problem financing provided by banks. The higher the ratio, the worse the quality of Islamic bank financing is. The level of soundness of financing also affects the achievement of bank profits. Funding management is much needed by banks, bearing in mind the function of financing as the biggest revenue contributor for Islamic banks. This is because the income received by banks will decrease and the costs for provisioning for write off receivables will increase resulting in profit decreases or losses increase (Kasmir, 2013). This is supported by the results of research conducted by Sari (2014) which states that if the portion of problematic financing increases, this will ultimately also affect the possibility of a decrease in the amount of profit / income obtained by banks. This decline in income will be able to affect the amount of profit of Islamic banks. In the end, it will affect the amount of profitability that is reflected in Return on Assets (ROA) obtained by Islamic banks. This is reinforced by research Almunawwaroh and Marliana (2018), Mokniand Rachidi (2014), Ben Khediri et al. (2010). For this reason, the first hypothesis for this research is:

\section{H1 : Non Performing Financing (NPF) affects profitability}

\section{Capital Adequacy Ratio (CAR)}

According to Ihsan (2015) Capital Adequacy Ratio (CAR) is the bank's capital adequacy ratio or is the ability of banks in existing capital to cover possible losses in credit or financing or losses in trading securities. The bigger the ratio, the better the capital position. According to Bank Indonesia regulation Number 10/15 / PBI / 2008 article 2 paragraph 1 it is stated that banks are required to provide a minimum capital of $8 \%$ of risk-weighted assets (ATMR). CAR is a capital indicator used as a variable that affects profitability (ROA) because it is based on its relationship with the level of bank risk. High capital ratios can protect depositors and have an impact on increasing public confidence in banks, and ultimately can increase ROA. The research results from Pratiwi (2015) states that with increasing own capital, bank health related to the capital ratio (CAR) is increasing and with large capital, the opportunity to obtain corporate profits is also getting bigger because with large capital, bank management is very free in placing funds into profitable investment activities. So it can be concluded that the higher the CAR, the higher the ROA, this shows the results that CAR affects ROA. This was confirmed by Almunawwaroh and Marliana (2018), 
Simatupang and Franzlay (2016) research, Rahmi and Anggraini (2013). For this reason, the second hypothesis for this study is:

\section{H2 : Capital Adequacy Ratio (CAR) affects profitability}

\section{Financing to Deposit Ratio (FDR)}

As explained earlier, Islamic banks do not introduce loans in the distribution of funds they collect. Therefore, the activity of channeling funds carried out by Islamic banks is more towards financing (financing). Financing to Deposit Ratio (FDR) shows the effectiveness of banks in channeling financing, if the FDR value is too high or too low then the bank is considered ineffective in raising funds and channeling funds obtained from customers, thereby affecting the profits obtained (Riyadi, 2014). According to (Dendawijaya, 2009) the maximum limit for Financing to Deposit Ratio (FDR) is $110 \%$, where if it exceeds the limit it means that bank liquidity is included in the bad category, some banking practitioners agreed on a safe limit of Financing to Deposit Ratio (FDR) of $80 \%$ with a tolerance limit of between $85 \%$ and $100 \%$. The greater the Financing to Deposit Ratio (FDR) means the greater the level of profitability. The greater FDR means the greater financing expansion channeled by banks. With the greater expansion of financing, the greater the profitability of banks because the income derived from financing, namely revenue sharing will be even greater. This is supported by the results of research conducted by Sabir et al (2012) and Erlangga (2016) which states that the higher the FDR within a certain threshold, the more bank profits will increase, assuming the bank is channeling funds for effective financing. With the increase in profits, the Return On Assets (ROA) will also increase. For this reason, the second hypothesis for this study is:

\section{H3 : Financing to Deposit Ratio (FDR) affects profitability}

\section{RESEARCH METHODS}

The research method used in this research is descriptive and verification methods. In this study, researchers took secondary data. The sampling technique uses purposive sampling with criteria:

(1) Companies in the banking sector in 2015-2018,

(2) Always publish his financial statements in the study period.

(3) Has complete ratio data

From 14 population of Islamic Commercial Bank Industry (BUS) in Indonesia, 12 samples were included in the study criteria. Data collection in this research is library technique and documentation technique by tracing historical data from the website www.idx.co.id, www.ojk.co.id, and www.bi.go.id. Data analysis using time series for 48 months or 4 years with multiple regression models. The regression model in this study is as follows:

$$
\mathrm{ROA}=\mathrm{a}+\beta_{1} \mathrm{NPF}+\beta_{2} \mathrm{CAR}+\beta_{3} \mathrm{FDR}+\mathrm{e}
$$

The analysis technique in this research uses descriptive statistical analysis and inferential statistics which include: classic assumption test (normality test, heteroscedasticity, multicollinearity, and autocorrelation), coefficient of determination, model testing using the F-Test, and hypothesis testing using the T-test with using SPSS 22 software. 


\section{FINDINGS AND DISCUSSION}

\section{Research Result}

Data to be used in the regression model must meet several classical assumption tests. According to Ghozali (2009), the models that presented can be analyzed and provide perspective results, first the BLUE (Best Linear Unlock Estimators) test is first performed to avoid the occurrence of deviations of classical assumptions so that problems do not arise in the use of multiple linear regression analysis by means of testing classical assumptions consisting of normality tests, autocorrelation tests, multicollinearity tests and heterokedasticity tests

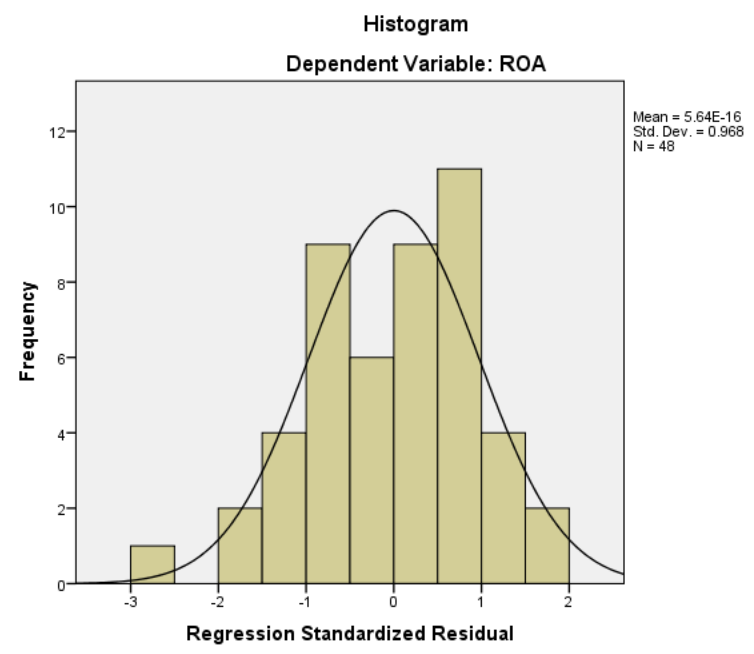

Figure 4.1 Normality Test Result

Based on the histogram image above, showing that the data is spread evenly (unevenly right or left aligned), it is stated that the data in this study are normally distributed.

Scatterplot

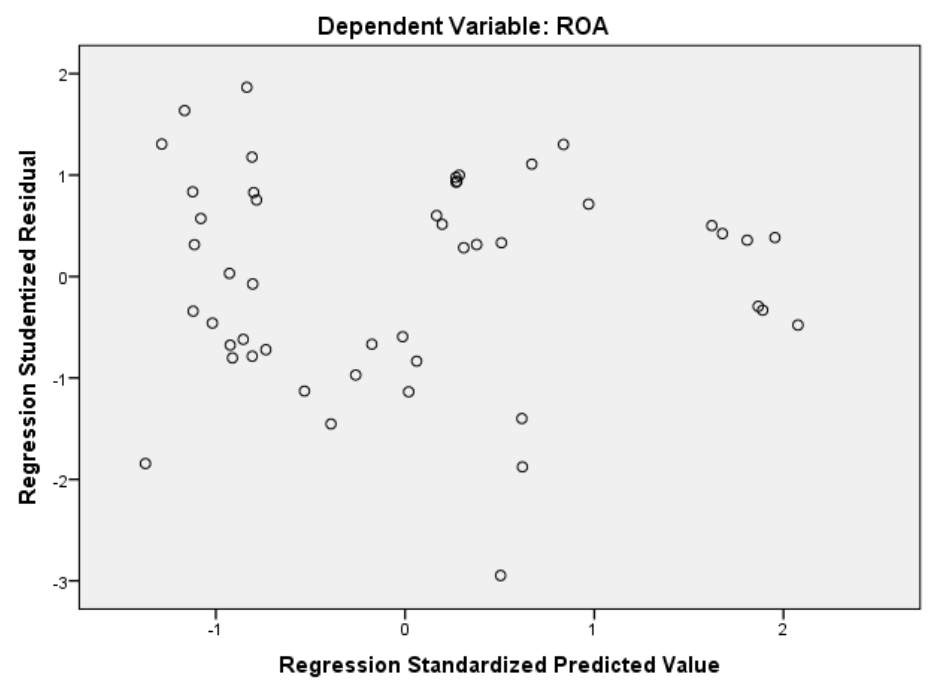

Figure 4.2 Heteroscedasticity Test Result 
Based on the scatterplot image above, it can be seen that the scattered points form unclear patterns above and below zero on the $\mathrm{Y}$ axis, so in the regression model there is no heteroscedastic problem.

Table 4.1. Multicollinearity Test Result

Coefficients $^{\mathrm{a}}$

\begin{tabular}{|c|c|c|c|}
\hline \multirow[b]{2}{*}{ Model } & & \multicolumn{2}{|c|}{ Collinearity Statistics } \\
\hline & & Tolerance & VIF \\
\hline \multirow[t]{4}{*}{1} & (Constant) & & \\
\hline & NPF & .343 & 2.912 \\
\hline & CAR & .178 & 3.607 \\
\hline & FDR & .281 & 3.554 \\
\hline
\end{tabular}

a. Dependent Variable: ROA

Multicollinearity test can be done with Tolerance (TOL) and Variance Inflation Factor (VIF) of each independent variable on the dependent variable.

In the Table 1 above, it can be seen that the VIF value is in the range of 1 or less than 10. This shows that the model is declared free from multicollinearity symptoms.

\section{Table 4.2. Autocorrelation Test Result}

\begin{tabular}{|c|c|c|c|c|c|}
\hline \multicolumn{6}{|c|}{ Model Summary } \\
\hline Model & $\mathrm{R}$ & R Square & $\begin{array}{l}\text { Adjusted R } \\
\text { Square }\end{array}$ & $\begin{array}{c}\text { Std. Error of the } \\
\text { Estimate }\end{array}$ & Durbin-Watson \\
\hline 1 & $.786^{\mathrm{a}}$ & .617 & .591 & 20.42395 & 1.910 \\
\hline
\end{tabular}

Durbin Watson's value shows 1,910. The value is close to number 2 or in the range of 2 to 2 . This shows that this study is free from autocorrelation symptoms.

Tabel 4.3 Research Test Result

\begin{tabular}{|c|c|c|c|c|c|c|}
\hline \multicolumn{7}{|c|}{ Coefficients ${ }^{a}$} \\
\hline \multirow[b]{3}{*}{ Model } & & \multirow{2}{*}{\multicolumn{2}{|c|}{ Unstandardized Coefficients }} & \multirow{3}{*}{$\begin{array}{c}\text { Standardized } \\
\text { Coefficients } \\
\text { Beta }\end{array}$} & \multirow[b]{3}{*}{$t$} & \multirow[b]{3}{*}{ Sig. } \\
\hline & & & & & & \\
\hline & & B & Std. Error & & & \\
\hline \multirow[t]{4}{*}{1} & (Constant) & .633 & .955 & & 1.010 & .318 \\
\hline & NPF & -.135 & .084 & -.256 & -8.609 & .015 \\
\hline & CAR & .059 & .033 & .398 & 5.804 & .018 \\
\hline & FDR & -.013 & .012 & -.188 & -7.072 & .020 \\
\hline
\end{tabular}

\begin{tabular}{|c|c|c|c|c|c|c|}
\hline \multicolumn{7}{|c|}{ ANOVA $^{\mathrm{a}}$} \\
\hline Model & & Sum of Squares & $\mathrm{df}$ & Mean Square & $\mathrm{F}$ & Sig. \\
\hline \multirow[t]{3}{*}{1} & Regression & 29614.261 & 3 & 9871.420 & 23.665 & $.000^{\circ}$ \\
\hline & Residual & 18354.051 & 44 & 417.138 & & \\
\hline & Total & 47968.312 & 47 & & & \\
\hline
\end{tabular}

\footnotetext{
a. Dependent Variable: ROA

b. Predictors: (Constant), FDR, NPF, CAR
} 
Based on table 4.3 above, the regression equation that will be formed is as follows:

$$
\text { ROA = 0,633 - 0,135NPF + 0,059CAR - 0,13FDR }
$$

The coefficient of determination $\left(\mathrm{R}^{2}\right)$ essentially measures how far the model's ability to explain variations in the dependent variable. In table 4.2 above (summary model table), the adjusted $R$-square value obtained is 0.617 . This shows that the three independent variables consisting of NPF, CAR and FDR contributed to the company's profitability of $61.7 \%$, while the remaining $38.3 \%$ is contributed by other variables that are not examined. Prob.F value in annova table of $0.000<0.05$ means that the regression model used is appropriate. In the coefficients table, the value of prob t. IHSG variable of $0.015<0.05$ means NPF has an effect on profitability, prob.t CAR is $0,018<0.05$ means that CAR has an effect on profitability, and prob.t variable FDR is $0.020<0.05$ which means that FDR has a significant effect on profitability. Then, based on data processing, the results are obtained that all independent variables consisting of Non Performing Financing (NPF), Capital Adequacy Ratio (CAR), and Financing to Deposit Ratio (FDR) affect profitability.

\section{The Effect of Non Performing Financing (NPF) on Profitability}

The test results show that the NPF variable has a significant effect on profitability with a negative relationship direction. This shows that the higher the NPF, the lower the profitability. The results are in line with previous studies conducted Ben Khediri et al. (2010), Mokniand Rachidi (2014), Medina and Rina (2017). NPF is the ratio used to find financing problems related to the possibility that at maturity the debtor of the fund fails to meet its obligations to the bank. So there is a need for caution by the bank in carrying out its functions. Risks in the form of difficulties in returning financing by a debtor with a large enough amount can affect bank performance. The existence of these problematic financing causes many of the financing that was distributed did not produce results and increased the company's operating expenses. This will certainly affect the company's profit. The high NPL also resulted in the emergence of larger reserves, thus causing a decline in the company's revenue and profits.

\section{The Effect of Capital Adequacy Ratio (CAR) on Profitability}

The test results show that the CAR variable has a significant effect on profitability with the direction of a positive relationship. This shows that the higher CAR will increase profitability. High or low ratio shows the level of bank liquidity, so the higher the value of FDR of a bank, it means it is described as a bank that is less liquid compared to banks that have smaller ratio numbers. Moreover, a high FDR indicates too high distribution of funds which is not followed by high collection of funds from the public (Third Party Funds). For this reason, all banks must have a balanced FDR value, not too high and not too low, so the ups and downs of FDR does not affect the profitability of the company because banks must maintain the value of FDR to the specified threshold. The results are in line with previous studies conducted by Almunawwaroh and Marliana (2018) and Erlangga (2016) 


\section{CONCLUSION AND SUGESTION}

Based on the results of statistical processing shows that all independent variables consisting of Non Performing Financing (NPF), Capital Adequacy Ratio (CAR), and Financing to Deposit Ratio (FDR) affect the profitability of the Sharia Commercial Bank Industry (BUS) in Indonesia from 2014 - 2018.

The results of this study provide advice to companies or Islamic banking, investors and further researchers. (1) Banks are expected to be able to monitor the amount of nonperforming financing (gross) so that assets and profits will be better, and be able to balance between the amount of financing provided with the funds raised so that funds are not deposited. Banks should tighten lending more and banking credit analysts should be more selective in granting credit to prospective creditors, so this can reduce the number of bad loans. (2) For Prospective Investors and Investors before depositing funds should pay attention to ratios related to the health performance of the bank concerned and a comprehensive picture of the bank, so as not to make wrong decisions, especially ratios related to banking risk and company liquidity. (3) The next researcher is expected to be able to replace the research sample to be studied and add variables such as BOPO, KAP and NIM in order to obtain better research results.

\section{REFERENCE}

Ahmad T. Alharbi, (2017). "Determinants of Islamic banks profitability: international evidence". International Journal of Islamic and Middle Eastern Finance and Management, Vol. 10 Issue: 3, pp.331-350

Almunawwaroh Medina, Marliana (2018). Pengaruh CAR, NPF, dan FDR terhadap Profitabilitas Bank Syariah Di Indonesia. Amwluna, Vol. 2 No. 1, Januari.

Bank Indonesia. Peraturan Bank Indonesia Nomor: 13/ 1 /PBI/2011 tentang Penilaian Tingkat Kesehatan Bank Umum.

Bank Indonesia, Peraturan Bank Indonesia Nomor: 13/24/DPNP tanggal 25 Oktober 2011 perihal Sistem Penilaian Tingkat Kesehatan Bank Umum.

Bank Indonesia. 2007. Surat Edaran No. 9/24/DPbS Perihal Sistem Penilaian Tingkat Kesehatan Bank Umum Berdasarkan Prinsip Syariah. Jakarta: Bank Indonesia.

Ben Khediri, K, Ben Ali (2010). "Bank Spesific, Industry Spesific and Macroeconomic Determinants of African Islamic bank Profitability". International Journal of Business and Management Science, Vol 3, pp. 39-56

Erlangga Okyviandi P (2016). Pengaruh Total Aktiva, CAR, FDR, NPF terhadap ROA Bank Umum Syariah di Indonesia Periode 2010-2014. Jurnal Ekonomi Syariah Teori dan Terapan Vol. 3 No.7 Juli.

Ghozali Imam. 2012. Aplikasi Analisis Multivaiate dengan Program IBM SPSS 22 Edisi 6. Semarang: Badan Penerbit Universitas Diponegoro.

Kasmir. 2013. Bank dan Lembaga Keuangan Lainnya. Edisi Revisi. Jakarta: Raja Gafindo Persada. 
Khediri Ben, (2009). "Determinants of Islamic Bank Profitability In The Mena Region". International Journal of Monetary Economics and Finance. Vol. 2. Nos 3/4, pp 209426.

Masood, O. and Ashraf, M. (2012). "Bank-Specific and and Macroeconomics Profitability Determinants of Islamic Banks : The Case of Different Countries". Qualitative Research in Financial Markets. Vol . 4 Nos 2/3, pp. 255-268.

McClave, James T. Dkk. 2011. Statistika untuk Bisnis dan Ekonomi Jilid 1 Edisi Kesebelas. Jakarta: Erlangga.

Mokni, R and Rachdi, H (2014). “Assessing The Bank Profitability In The MENA region : A Comparative Analysis Between Conventional and Islamic Bank". International Journal of Islamic and Middle Eastern Finance and Management Science, Vol. 3, pp $39-56$.

Paulin and Wiryono (2015). "Determinants of Islamic Bank's Profitability in Indonesia". Journal of Business and Management, Vol 4

Rahmi Nurul and Anggraini (2013). Pengaruh CAR, BOPO, NPF, dan CSR Disclosure Terhadap Profitabilitas Perbankan Syariah. Jurnal Ilmiah Wahana Akuntansi. Volume 8, No.2.

Samad, A., and Hassan, M. K. (n.d.). "The Performance of Malaysian Islamic Bank During 1984-1997: An Exploratory Study". International Journal of Islamic Financial Services Vol. 1 No.3 , 1.

Simatupang, Apriani and Smarzlay (2016). "Pengaruh CAR, NPF, BOPO dan FDR terhadap Profitabilitas Bank Umum Syariah di Indonesia". Jurnal administrasi kantor: volume 4, No 2 Des 2016

Siraj, K., and Pillai, P. S. (2012). "Comparative Study on Performance of Islamic Banks and Conventional Banks in GCC Region". Journal of Applied Finance and Banking, 149.

Smaoui, H. and Salah, I. (2011). "Profitability of Islamic Bank In The GCC Region". Paper Presented At The Annial Paris Conference, Money, Economy and Management, World Academy of Social Science, Paris, 14-15 July, World Business Institute Australia, Avaliable at : www.wbiconpro.com/615-Houcem.pdf .

Subaweh, et al. 2012. "Analysis of Financial Allocation and Its Impact on The Profitability of Islamic Banking in Indonesia". The First International Credit Union Conference on Social Microfinance and Community Development, BKCU Kalimantan Gunadarma University, 111.

www.bi.go.id

www.cnbcindonesia.com

www.ojk.co.id 